\title{
PENGARUH PEMBERIAN BAHAN ORGANIK TERHADAP SIFAT KIMIA PADA TANAH SAWAH TERDEGRADASI DI KECAMATAN PANTAI LABU KABUPATEN DELI SERDANG
}

Salman Alfarisi, Deni Elfiati \& Abdul Rauf

Program Studi Pascasarjana Fakultas Pertanian USU, Medan

*Corresponding author: salmanalfarisi86medan@gmail.com

\begin{abstract}
Organic fertilizers provide an advantage in increasing the growth and yield, and can reduce the use of inorganic fertilizers. The study aims to analyze the land rehabilitation efforts relegated to improve the properties of the fields of chemistry, physics, and biology of the soil, with compare paddy soil conditions before and after rehabilitation. thereby increasing the productivity of rice in the District of Pantai Labu. The research was conducted in Durian, District, Pantai Labu, Deli Serdang, North Sumatra in April 2017 to July 2017. The study was arranged in a randomized block design (RAK) non factorial experiment with five treatments and four replications. The treatments used are $B_{0}=$ Control, $B_{1}=1.5 \%, B_{2}=3 \%, B_{3}=4.5 \%, B_{4}=6 \%$. The results showed that organic fertilizer can increase plant growth indicated by an increase in plant height. Organic fertilizers also increase the number of productive tillers, panicle length. Organic fertilizers also increase the number of grains per panicle and filled grain.
\end{abstract}

Keywords: the growth of rice, organic fertilizer

\begin{abstract}
ABSTRAK
Pemanfaatan Pupuk organik memberikan keuntungan dalam meningkatkan pertumbuhan dan hasil tanaman, serta dapat mengurangi penggunaan pupuk anorganik. Penelitian bertujuan untuk Menganalisis upaya rehabilitasi tanah sawah terdegradasi dengan memperbaiki sifat kimia, fisika, dan biologi tanah, dengan membadingkan kondisi tanah sawah sebelum dan sesudah direhabilitasi. sehingga dapat meningkatkan produktivitas padi di Kecamatan Pantai Labu. Penelitian dilaksanakan di Desa Durian, Kecamatan, Pantai Labu, Kabupaten Deli Serdang, Sumatera Utara pada bulan April 2017 sampai Juli 2017. Penelitian disusun dalam Rancangan Acak Kelompok (RAK) Non Faktorial dengan lima perlakuan percobaan dan empat ulangan. Perlakuan yang digunakan adalah $\mathrm{B}_{0}=$ Kontrol, $\mathrm{B}_{1}=1,5 \%, \mathrm{~B}_{2}=3 \%, \mathrm{~B}_{3}=4,5 \%, \mathrm{~B}_{4}=6 \%$. Hasil penelitian menunjukkan bahwa pupuk organik dapat meningkatkan pertumbuhan tanaman yang ditunjukkan dengan peningkatan tinggi tanaman. Pupuk organik juga meningkatkan jumlah anakan produktif, panjang malai. Pupuk organik juga meningkatkan jumlah gabah per malai dan persen gabah isi.
\end{abstract}

Kata Kunci: pertumbuhan padi, pupuk organik

\section{PENDAHULUAN}

Tanah merupakan media alami bagi tanaman untuk tumbuh dan berkembang. Jika tanah rusak maka tanaman tidak akan tumbuh secara optimal. Hal ini disebabkan karena sumber utama nutrisi yang dibutuhkan tidak cukup tersedia atau tidak terserap dengan baik.
Indonesia merupakan bagian dari ekosistem tropika basah yang tergolong sangat rentan terhadap degradasi jika pengelolaannya tidak tepat. Ekosistem tropika basah meliputi areal sekitar 1,5 milyar hektar lahan dengan populasi manusia sekitar 2 milyar, yang tersebar dalam 60 negara. Dua puluh lima persen areal tersebut terdapat di Asia. Umumnya faktor-faktor penyebab 
degradasi tersebut baik secara alami maupun campur tangan manusia menimbulkan kerusakan dan menurunnya produktivitas tanah (Made et al., 2010).

Kondisi iklim Indonesia bagian barat di Sumatera Utara, khususnya Kecamatan Pantai Labu Kabupaten Deli Serdang seperti curah hujan dan suhu yang tinggi, menyebabkan tanah-tanahnya mudah terdegradasi menjadi lahan kritis. Kerusakan tanah yang terjadi pada umumnya karena rendahnya kandungan bahan organik. Lebih dari 60\% lahan sawah di Indonesia memiliki kandungan bahan organik yang rendah sampai sangat rendah (Djaenuddin, et. al, 2003). Sehingga untuk mengatasi hal tersebut tentunya perlu tambahan bahan organik, yaitu dengan menggunakan pupuk organik sesuai dengan pernyataan Firmansyah (2003) yang menyatakan bahwa bahan organik lebih efektif untuk tanah dengan kompaktilitas tinggi, ketahanan penetrasi maksimum tanah liat menurun dari 0,64 menjadi $0,30 \mathrm{Mpa}$, dan pada tanah berpasir meningkat dari 0,64 menjadi 1,08 Mpa. Pemberian bahan tersebut dapat memperbaiki sifat fisik tanah berupa peningkatan total ruang pori, perbaikan aerasi tanah, pori air tersedia, permeabilitas tanah dan menurunnya ketahanan penetrasi, sehingga dapat merehabilitasi tanah yang terdegradasi untuk mendukung pertumbuhan, perkembangan, dan produksi tanaman padi yang optimal di Kecamatan Pantai Labu.

\section{BAHAN DAN METODE}

Penelitian ini dilaksanakan di Kecamatan Pantai Labu Kabupaten Deli Serdang yang memiliki luas $81,85 \mathrm{Km}^{2}$ (8.185 Ha) (BPS Deli Serdang,2016). Penelitian ini dilaksanakan dari bulan April 2017 sampai Juli 2017.

Bahan yang digunakan dalam penelitian ini adalah sampel tanah yang diambil dari lokasi penelitian pada setiap Satuan Peta Lahan (SPL), Benih padi Varietas Ciherang, Pupuk Organik Sampah Kota, Pupuk Dasar (Urea, SP 36 dan $\mathrm{KCl}$ ) yang diaplikasikan pada umur 7 hari setelah tanam (HST) yaitu $150 \mathrm{~kg} / \mathrm{ha}$ urea $(0,3 \mathrm{~kg} / \mathrm{plot}), 100$ $\mathrm{kg} / \mathrm{ha}$ SP-36 (0,2 kg/plot) dan $50 \mathrm{~kg} / \mathrm{ha} \mathrm{KCl}$
$(0,1 \mathrm{~kg} / \mathrm{plot})$ dan pada umur $42 \mathrm{HST}$ yaitu 50 $\mathrm{kg} / \mathrm{ha} \mathrm{KCl}(0,1 \mathrm{~kg} / \mathrm{plot})$. Insektisida, fungisida dan bahan yang dibutuhkan lainnya, serta bahan - bahan kimia yang digunakan untuk analisis di laboratorium.

Alat yang digunakan dalam penelitian ini adalah Peta Satuan Peta Lahan (SPL) Kecamatan Pantai Labu skala 1 : 50.000. Peta Satuan Peta Lahan (SPL) di buat berdasarkan Peta Jenis Tanah, Peta Kemiringan Lereng dan Peta Ketinggian Tempat, Global Positioning System (GPS) untuk mengetahui titik koordinat dan ketinggian tempat, Aklinometer untuk mengukur kemiringan lereng, bor tanah untuk mengambil contoh tanah, kertas label untuk memberi label sample tanah, kantung plastik sebagai wadah sample tanah, karet gelang untuk mengikat sample tanah dalam kantung plastik, , spidol, alat tulis, serta alat-alat yang digunakan untuk analisis di laboratorium, serta cangkul, hand traktor, gembor, tugal, tali rafia, meteran, gunting, pisau, pacak sampel, papan nama, handsprayer, kamera, alat tulis dan alat yang dibutuhkan lainnya.

\section{Aplikasi Bahan Organik}

Aplikasi bahan organik dilakukan satu minggu sebelum penanaman, dengan dosis seperti perlakuan yaitu $\mathrm{B}_{0}=$ Kontrol, $\mathrm{B}_{1}=$ $1,5 \%$ (40,80 ton/ha atau $326 \mathrm{~kg} / \mathrm{plot}), \mathrm{B}_{2}=3$ $\%(81,60$ ton $/$ ha atau $653 \mathrm{~kg} / \mathrm{plot}), \mathrm{B}_{3}=4,5 \%$ $(122,4$ ton/ha atau $979 \mathrm{~kg} / \mathrm{plot})$ dan $\mathrm{B}_{4}=6 \%$ (163,2 ton/ha atau $1.306 \mathrm{~kg} / \mathrm{plot})$.

Aplikasi bahan Organik yang digunakan adalah Pupuk Kompos dengan komposisi Kompos Sampah Domestik (Sampah Kota) + Pupuk Kandang Sapi/Domba + Blotong + Air Seni dan Cucian Kandang Sapi dengan perbandingan $5: 5: 5: 1$

\section{Metode Penelitian}

Penelitian

ini menggunakan

Rancangan Acak Kelompok (RAK) non Faktorial dengan perlakuan dosis bahan organik (B), yang terdiri dari 5 (lima) taraf yaitu $\mathrm{B}_{0}=$ Kontrol, $\mathrm{B}_{1}=1,5 \%(40,80$ ton/ha), $\mathrm{B}_{2}=3 \% \quad\left(81,60\right.$ ton/ha), $\mathrm{B}_{3}=4,5$ $\% \quad(122,4$ ton/ha $), \mathrm{B}_{4}=6 \% \quad(163,2$ ton/ha), dengan jumlah blok 4, jumlah perlakuan 5, jumlah Plot Percobaan 20, luas 
plot percobaan $4 \mathrm{~m} \times 5 \mathrm{~m}$, jumlah tanaman dalam 1 plot 400 tanaman dan jumlah sampel per plot 8 tanaman.

\section{HASIL DAN PEMBAHASAN}

\section{Sifat KimiaTanah pH Tanah}

Bahan organik berpengaruh nyata terhadap $\mathrm{pH}$ tanah. Rataan pHtanah dapat dilihat pada Tabel 1.

Tabel 1. Pengaruh Pemberian Bahan Organik Terhadap Rataan $\mathrm{pH}$ Tanah

\begin{tabular}{cc}
\hline Perlakuan & $\mathrm{pH}$ \\
& Tanah \\
\hline Kontrol $(0 \mathrm{Ha})$ & $6.16 \mathrm{c}$ \\
40,80 ton $/ \mathrm{Ha}$ & $6.14 \mathrm{c}$ \\
$81,60 \mathrm{ton} / \mathrm{Ha}$ & $6.29 \mathrm{~b}$ \\
$122,40 \mathrm{ton} / \mathrm{Ha}$ & $6.28 \mathrm{~b}$ \\
$163,20 \mathrm{ton} / \mathrm{Ha}$ & $6.43 \mathrm{a}$ \\
\hline
\end{tabular}

Keterangan: Angka-angka yang diikuti notasi yang sama pada kelompok kolom yang sama menunjukkan tidak berbeda nyata pada taraf $5 \%$ menurut Duncan Multiple Range Test.

Dari rataan Tabel 1. Dapat di lihat bahwa perlakuan 0 ton/Ha berbeda tidak nyata dengan perlakuan 40,80 ton/Ha sedangkan perlakuan 163,20 ton/Ha merupakan rataan tertinggi dalam meningkatkan $\mathrm{pH}$ tanah sebesar 6,43. Bahan organik juga dapat meningkatkan $\mathrm{pH}$ tanah,Noor et al. (2005) menjelaskan bahwa perubahan kondisi reduktif-oksidatif menyebabkan terjadinya perubahan muatan unsur-unsur redoks. Unsur fero $\left(\mathrm{Fe}^{2+)} 24\right.$ dan mangano $\left(\mathrm{Mn}^{4+)}\right.$ berubah menjadi feri $\left(\mathrm{Fe}^{3+}\right)$ dan mangani $\left(\mathrm{Mn}^{4+)}\right.$ yang lebih stabil dalam mengikat ion hidroksida $\left(\mathrm{OH}^{-}\right)$serta melepaskan hidrogen $\left(\mathrm{H}^{+}\right)$.

\section{C-Organik, N-Total,dan Rasio C/N}

Bahan organik berpengaruh terhadap COrganik, N-Total, dan Rasio C/N. Rataan COrganik,N-Total,dan Rasio C/N dapat dilihat pada Tabel 2.

Tabel 2. Pengaruh Pemberian Bahan Organik Terhadap Rataan C-Organik (\%), N Total(\%), dan Rasio C /N.

\begin{tabular}{|c|c|c|c|}
\hline Perlakuan & $\begin{array}{c}\text { C- } \\
\text { Organik } \\
(\%)\end{array}$ & $\begin{array}{c}\mathrm{N}- \\
\text { Total } \\
(\%)\end{array}$ & $\begin{array}{c}\text { Rasio } \\
\text { C/N }\end{array}$ \\
\hline Kontrol (0 & & & 4.40 \\
\hline Нa) & $0.72 \mathrm{c}$ & $0.15 \mathrm{~d}$ & b \\
\hline 40,80 & & & 2.66 \\
\hline ton/Ha & $0.79 \mathrm{c}$ & $0.29 \mathrm{c}$ & $\mathrm{c}$ \\
\hline 81,60 & & & 4.45 \\
\hline ton/Ha & $1.49 \mathrm{~b}$ & $0.33 \mathrm{c}$ & $\mathrm{b}$ \\
\hline 122,40 & & & 5.80 \\
\hline ton/Ha & $2.35 \mathrm{a}$ & $0.40 \mathrm{~b}$ & $\mathrm{a}$ \\
\hline 163,20 & & & 5.09 \\
\hline ton/Ha & $2.51 \mathrm{a}$ & $0.48 \mathrm{a}$ & $a b$ \\
\hline Keterangan: & \multicolumn{3}{|c|}{$\begin{array}{l}\text { Angka-angka yang diikuti } \\
\text { notasi yang sama pada } \\
\text { kelompok kolom yang sama } \\
\text { menunjukkan tidak berbeda } \\
\text { nyata pada taraf } 5 \% \text { menurut } \\
\text { Duncan Multiple Range Test }\end{array}$} \\
\hline
\end{tabular}

Dari rataan Tabel 2. Untuk rataan COrganik dapat dilihat bahwa perlakuan 122,40 ton/Ha berbeda tidak nyata dengan perlakuan 163,20 ton/Ha, dan perlakuan 163,20 ton/Ha merupakan rataan tertinggi sebesar 2,51\% dalam meningkatkan meningkatkan COrganik. Pemberian pupuk organik akan mampu meningkatkan ketersediaan unsur hara dan meningkatkan C-organik tanah. Pupuk organik memiliki sifat slow release sehingga akan mampu meningkatkan pertumbuhan dan hasil tanaman.

Untuk rataan $\mathrm{N}$ Total(\%) dapat dilihat bahwa perlakuan 163,20 ton/Ha berbeda nyata dengan perlakuan lainnya, dan perlakuan 163,20 ton/Ha merupakan rataan yang tertinggi dalam meningkatkan $\mathrm{N}$-total sebesar 0,48\%. Aplikasi pupuk organik (kandang sapi, kompos temesi) umumnya tidak mengganggu ketersediaan $\mathrm{N}$, tetapi dapat menyerap $\mathrm{N}$. Walaupun bahan organiknya belum selesai, pertumbuhan dan hasil jauh lebih baik dan tinggi dibandingkan dengan pupuk anorganik (Yuwono, 2005) Bahan organik sumber nitrogen (protein) pertamatama akan mengalami peruraian menjadi asam-asam amino yang dikenal dengan proses aminisasi, yang selanjutnya oleh sejumlah besar mikrobia heterotrofik mengurai menjadi amonium yang dikenal sebagai proses amonifikasi. amonium ini yang merupakan 
bentuk nitrogen anorganik (mineral) yang utama dalam tanah (Tisdel dan Nelson, 1974).

Untuk rataan Rasio $\mathrm{C} / \mathrm{N}$ dapat dilihat bahwa perlakuan 122,40 ton/Ha merupakan rataan tertinggi dalam meningkatkan rasio $\mathrm{C} / \mathrm{N}$ sebesar 5,80 .

\section{Kadar Bahan Organik}

Bahan organik berpengaruh nyata terhadap kadar bahan organik. Rataan kadar bahan organik dapat dilihat padaTabel 5 .

Tabel 5. Pengaruh Pemberian Bahan Organik Terhadap Rataan Kadar Bahan Organik (\%)

\begin{tabular}{cc}
\hline Perlakuan & $\begin{array}{c}\text { Kadar } \\
\text { Bahan } \\
\text { Organi } \\
\mathrm{k}(\%)\end{array}$ \\
\hline Kontrol $(0 \mathrm{Ha})$ & $1.24 \mathrm{c}$ \\
$40,80 \mathrm{ton} / \mathrm{Ha}$ & $1.21 \mathrm{c}$ \\
$81,60 \mathrm{ton} / \mathrm{Ha}$ & $2.56 \mathrm{~b}$ \\
$122,40 \mathrm{ton} / \mathrm{Ha}$ & $3.85 \mathrm{a}$ \\
$163,20 \mathrm{ton} / \mathrm{Ha}$ & $4.14 \mathrm{a}$ \\
\hline
\end{tabular}

Keterangan: Angka-angka yang diikuti notasi yang sama pada kelompok kolom yang sama menunjukkan tidak berbeda nyata pada taraf $5 \%$ menurut Duncan Multiple Range Test.

Dari rataan Tabel 5. dapat dilihat bahwa perlakuan 122,40 ton/Ha berbeda tidak nyata dengan perlakuan 163,20 ton/Ha, dan perlakuan 163,20 ton/Ha merupakan rataan tertinggi dalam meningkatkan kadar bahan organik sebesar 4,14\%. Pemberian pupuk organik akan berpengaruh terhadap proses perombakan bahan organik, dan pembentukan humus dalam tanah sangat tergantung pada adanya mikroba penyubur tanah dan perombakan bahan organik. Pemanfaatan mikroba perombak bahan organik untuk percepatan perombakan bahan organik dapat meningkatkan biomassa dan aktivitas mikroba tanah, mengurangi penyakit, larva insek, biji gulma, dan volume bahan buangan, yang pada gilirannya dapat meningkatkan kesuburan dan kesehatan tanah

(Saraswati, 2007).Pemanfaatan mikroba perombak bahan organik untuk percepatan perombakan bahan organik dapat meningkatkan biomassa dan aktivitas mikroba tanah, mengurangi penyakit, biji gulma, dan volume bahan buangan, yang dapat meningkatkan kesuburan dan kesehatan tanah (Saraswati, 2007).

\section{P-Tersedia}

Bahan organikberpengaruh nyata terhadap P-tersedia. Rataan P-tersedia dapat dilihat pada Tabel 6 .

Tabel 6. Pengaruh Pemberian Bahan Organik Terhadap Rataan P-Tersedia (ppm)

\begin{tabular}{cc}
\hline Perlakuan & $\begin{array}{c}\text { Persedia } \\
(\mathrm{ppm})\end{array}$ \\
\hline Kontrol (0 Ha) & $12.55 \mathrm{c}$ \\
40,80 ton/Ha & $16.80 \mathrm{~b}$ \\
$81,60 \mathrm{ton} / \mathrm{Ha}$ & $17.03 \mathrm{~b}$ \\
$122,40 \mathrm{ton} / \mathrm{Ha}$ & $17.69 \mathrm{~b}$ \\
163,20 ton/Ha & $20.66 \mathrm{a}$ \\
\hline Keterangan: & Angka-angka yang diikuti \\
& notasi yang sama pada \\
& kelompok kolom yang sama \\
& menunjukkan tidak berbeda \\
& nyata pada taraf 5\% menurut \\
& Duncan Multiple Range Test.
\end{tabular}

Dari rataan Tabel 6. dapat dilihat bahwa perlakuan 163,20 ton/Ha berbeda nyata dengan perlakuan lainnya dan merupakan rataan yang tertinggi dalam meningkatkan Ptersedia sebesar 20,66 ppm. Hal ini di sebabkan pengaruh bahan organik terhadap ketersediaan $\mathrm{P}$ dapat secara langsung melaui proses mineralisasi atau secara tidak langsung dengan membantu pelepasan $\mathrm{P}$ yang terfiksasi. Bahan organik yang diberikan ke dalam tanah, melalui aktivitas asam-asam organik yang dihasilkan, mampu melepaskan ikatan $\mathrm{P}$ yang terfiksasi dalam bentuk Al-P, Fe-P dan Ca-P sehingga menjadi $\mathrm{P}$ tersedia (Hakim et al., 1986). Pemberian bahan organik dapat meningkatkan ketersedian $\mathrm{P}$, karena bahan organik di dalam tanah berperan dalam hal : pembentukan kompleks organofosfat yang mudah diassimilasi oleh tanaman, pergantian anion $\mathrm{H}_{2} \mathrm{PO}^{4-}$ pada tapak jerapan penyelimutan oksida $\mathrm{Fe} / \mathrm{Al}$ oleh 
humus yang membentuk lapisan pelindung dan mengurangi penjerapan $\mathrm{P}$, dan meningkatkan jumlah $\mathrm{P}$ organik yang dimineralisasi menjadi $\mathrm{P}$ anorganik (Havlin et al., 1999).

diberikan ke dalam tanah, melalui aktivitas asam-asam organik yang dihasilkan, mampu melepaskan ikatan $\mathrm{P}$ yang terfiksasi dalam bentuk Al-P, Fe-P dan Ca-P sehingga menjadi $\mathrm{P}$ tersedia (Hakim et al ., 1986). Pemberian bahan organik dapat meningkatkan ketersedian P, karena bahan organik di dalam tanah berperan dalam hal : pembentukan kompleks organofosfat yang mudah diassimilasi oleh tanaman, pergantian anion $\mathrm{H}_{2} \mathrm{PO}^{4-}$ pada tapak jerapan penyelimutan oksida Fe/Al oleh humus yang membentuk lapisan pelindung dan mengurangi penjerapan $\mathrm{P}$, dan meningkatkan jumlah $\mathrm{P}$ organik yang dimineralisasi menjadi $\mathrm{P}$ anorganik (Havlin et al., 1999).

\section{Kapasitas Tukar Kation (KTK) Tanah}

Bahan organikberpengaruh nyata terhadap KTK tanah. Rataan KTK tanahdapat dilihat padaTabel 7.

Tabel 7. Pengaruh Pemberian Bahan Organik Terhadap Rataan KTK Tanah (me kation/100g Tanah)

\begin{tabular}{cc}
\hline Perlakuan & $\begin{array}{c}\text { KTK Tanah } \\
\text { (me } \\
\text { kation/100 g } \\
\text { Tanah) }\end{array}$ \\
\hline Kontrol $(0 \mathrm{Ha})$ & $17.68 \mathrm{c}$ \\
40,80 ton $/ \mathrm{Ha}$ & $18.29 \mathrm{bc}$ \\
$81,60 \mathrm{ton} / \mathrm{Ha}$ & $18.40 \mathrm{bc}$ \\
$122,40 \mathrm{ton} / \mathrm{Ha}$ & $19.24 \mathrm{~b}$ \\
$163,20 \mathrm{ton} / \mathrm{Ha}$ & $22.92 \mathrm{a}$ \\
\hline
\end{tabular}

Keterangan: Angka-angka yang diikuti notasi yang sama pada kelompok kolom yang sama menunjukkan tidak berbeda nyata pada taraf $5 \%$ menurut Duncan Multiple Range Test.

Dari rataan Tabel 7. dapat dilihat bahwa perlakuan 163,20 ton/Ha berbeda nyata dengan perlakuan lainnya dan merupakan rataan yang tertinggi dalam meningkatkan KTK tanah sebesar 22,92 me kation/100 g tanah. Pupuk organik memberikan nilai KTK yang tinggi Penambahan pupuk organik ini mengakibatkan cbertambahnya jumlah keloid organik yang berperan dalam pertukaran kation dalam tanah. Hanafiah (2005) menjelaskan bahwa humus dari bahan organik merupakan koloidal organik yang bermuatan listrik dan secara kimia berperan dalam menentukan kapasitas pertukaran kation sehingga berpengaruh penting terhadap ketersediaan hara tanah. Hasil dari mineralisasi bahan organik merupakan anion/kation hara yang tersedia bagi tanaman. Lebih lanjut dijelaskan oleh Hardjowigeno (2003) bahwa tanah-tanah yang memiliki kandungan bahan organik tinggi cenderung memiliki KTK yang tinggi.

\section{SIMPULAN}

Pemberian pupuk organik memberikan pengaruh terhadap sifat kimia tanah sawah di Kecamatan Pantai Labu Kabupaten Deli Serdang, dan pemberian pupuk dengan dosis 40,80 ton/Ha dapat memperbaiki sifat tanah dan produksi tanaman padi.

\section{DAFTAR PUSTAKA}

BPS 2016. Kecamatan Pantai Labu dalam angka 2016. Diakses tanggal 28 Maret 2017

Djaenuddin, D., H. Marwan., H. Subagjo., danA. Hidayat. 2003. Petunjuk Teknis Evaluasi lahan untuk Komoditas Pertanian. Balai Penelitian Tanah, Puslitbangtanak, Bogor $154 \mathrm{hlm}$.

Firmansyah, M. A. 2003. Resiliensi tanah terdegradasi. IPB. Bogor.

Hakim. N., Nyakpa. Y. M., A.M. Lubis., Nugroho., M.R. Saul., M.A. Diha., G.B. Hong., dan H.H. Bailey. 1986. Dasar-Dasar Ilmu Tanah. Universitas Lampung Press. Bandar Lampung.

Hanafiah, K , 2005. Dasar-dasar Ilmu Tanah. Jakarta: Raja Grafindo Persada 
Hardjowigeno, Sarwono, 2003. Klasifikasi

Tanah dan Pedogenesis. Jakarta: akademika Pressindo

Havlin,J.L., J.D. Beaton, S.L. Tisdale and W.L. Nelson, 1999. Soil Fertility and Fertilizers An Introduction to Nutrient Management. $6^{\text {th }}$ ed. Prentice Hall, Upper Sadle River, New Jersey, pp. 497

Made, I Mega., I Nyoman Dibia, IGP Ratna, dan Kusmiyarti. 2010. Klasifikasi Tanah danKesesuaian Lahan. FP. Udayana. Denpasar.

Noor, M. 2005. Pertanian Lahan Gambut. Yogyakarta: Kanisius

Saraswati, R. 2007. Pengembangan Teknologi Mikroflora Tanah Multiguna untuk Efisiensi Pemupukan dan Keberlanjutan Prouktivitas Lahan Pertanian.

Pusat Penelitian dan

Pengembangan Tanah dan Agroklimat Bogor.

Tisdale, S.L., and Nelson, W.L. (1975)Soil Fertility and Fertilizers. Third Edition. mac Millan Pub. Co. Inc. New York.

Yuwono, 2005. Psikologi Industri dan Organisasi. Surabaya: Fakultas Psikologi Universitas Airlangga 